\title{
PRIVATE POLITICS DAILY: WHAT MAKES FIRMS THE TARGET OF INTERNET/MEDIA CRITICISM? AN EMPIRICAL INVESTIGATION OF FIRM, INDUSTRY, AND INSTITUTIONAL FACTORS
}

\author{
Dominik Breitinger and Jean-Philippe Bonardi
}

\begin{abstract}
Private politics refers to situations in which activists or NGOs try to push firms to conform to social standards (regarding, for instance, human rights and environmental protection) without public policy intervention. The existing literature on private politics has focused on large campaigns such as consumer boycotts, and looked at the impact of those boycotts on firms' financial performance and on the likelihood that firms comply with activist demands. Even though these large campaigns are important, focusing on them leads to neglecting the fact that a large portion of the time and resources that activists consecrate to private politics is used to monitor firms and criticize them through Internet posting and media statements, rather than to launch high profile campaigns. Little is known,
\end{abstract}

\footnotetext{
Strategy Beyond Markets

Advances in Strategic Management, Volume 34, 331-363

Copyright (C) 2016 by Emerald Group Publishing Limited

All rights of reproduction in any form reserved

ISSN: 0742-3322/doi:10.1108/S0742-332220160000034010
} 
however, about what drives these activists when they criticize companies, why they target certain companies and not others, and whether this criticism should be considered as a primary step in the production of full-fledged campaigns. In this paper, we fill this gap by exploring a unique international database of CSR-based criticisms against Fortune 500 companies for the 2006-2009 period. This database allows us to look at the impact of a broad range of factors including industry differences, country/institutional differences and firm-specific dimensions, on the likelihood that a certain firm will be targeted by activist critique. Results indicate that criticism is driven by strategic intents. Similar to previous literature, large and visible firms in certain industries are more targeted than others. In addition, these firms also tend to come from countries with strong institutions and high standards of living.

Keywords: Private politics; activists; Internet/media criticism

\section{INTRODUCTION}

Within the field studying firms' nonmarket strategies (Baron, 2003), private politics - in which activists launch campaigns and target firms in order to get them to change their practices - has become more and more important (Beck, 2000; King \& Pearce, 2010). Whereas public politics - in which activists and other interest groups compete against firms in lobbying for public policy changes (Kingsley, Vanden Bergh, \& Bonardi, 2012) - is often perceived as uncertain and difficult to manage, private politics has indeed proven to be an effective way for activists to reach their goals and push firms to self-regulate (Baron \& Diermeier, 2007; Bunn, 2003-2004). These activists have evolved into well-organized civil society groups that diligently scrutinize business practices (Yaziji \& Doh, 2009). To make uncovered social/environmental issues salient, NGOs dispose of an arsenal of weapons to target or hit firms, ranging from letter writing campaigns to media criticism (Bonardi \& Keim, 2005), boycotts (Friedman, 1985) and public, sometimes violent, campaigns (Teegen, Doh, \& Vachani, 2004). NGOs, therefore, make use of "radio, television and newspaper ads to condemn practices of particular firms, organize boycotts, sit-ins, customer confrontations; and employ face-to-face challenges in the form of blockades, protests, banner-hangs, and so on" (Sasser, Prakash, Cashore, \& Graeme, 2006, p. 06). 
The academic literature has recognized this growing trend, and the number of studies regarding private politics has risen significantly in recent years. Theoretical pieces argue that activists, when they implement anticorporate campaigns, pick their targets strategically based on the cost of consumers switching to other products, as well as on how costly the campaign will be for the target (Baron \& Diermeier, 2007). In particular, companies with a strong brand name or a high level of reputation are more likely to be targeted by activists' campaigns (King, 2008). Empirical studies on the phenomenon confirm that target selection is heavily influenced by target characteristics: companies that are large, visible, and financially successful seem to be preferred targets (King \& Soule, 2007). Some studies also argue that an affiliation to certain industries, particularly polluting industries, also matters (Lenox \& Eesley, 2009). Rehbein, Waddock, and Graves (2004) analyze 1,944 laborand environmental-related shareholder resolutions against 600 US firms in the 1990s. They provide evidence that companies with inferior social performance significantly receive more shareholder resolutions. Likewise, companies that "have produced products that have negative contingencies are preferred stakeholder targets" Rehbein et al. (2004, p. 261). The study by Lenox and Eesley (2009) examines the selection (targeting) and response strategies of 552 environmental campaigns organized against 273 US firms between 1988 and 2003. They find, similar to Rehbein et al., that smaller, less visible firms are less likely to be targeted.

One limitation of this literature, however, is that it tends to concentrate on large and very visible events such as boycotts (John \& Klein, 2003; King, 2008; Koku, Akhigbe, \& Springer, 1997) or large campaigns (Eesley \& Lenox, 2006). In doing so, this literature neglects the fact that most of what activists do is often more mundane and related to monitoring and criticizing firms over the Internet or in the media, but without necessarily launching these large campaigns. A significant part of activist behavior in private politics has therefore not been studied empirically. Several questions emerge as a result: Do activists pick corporate targets in the same way for mundane criticism as they do for large campaigns? What drives activist behavior for daily private politics, and what determines the intensity of the pressure these activists put on firms?

Beyond studying why certain firms are targeted, this paper thus aims at a better understanding of what drives activist behavior. Activists are presented in the literature as playing two roles regarding firms and environmental or social issues. First, activists can play a monitoring role: scan firms' activities around the world and act as whistleblowers when bad behaviors are spotted. This role is seen as particularly important when multinational firms, using 
globalization to their advantage, operate in countries in which institutional structures are too weak to prevent bad behaviors (Scherer \& Palazzo, 2011). In this case, we should observe that activist targeting activities focus on firms, mostly from developed countries, creating environmental and social issues abroad. Second, activists can also use firms to gather attention to their cause and build reputation or legitimacy (Den Hond \& de Bakker, 2007). This is what we call here the "strategic" motive for activism. In this case, they will target well-known and visible firms, and even potentially CSRoriented firms, as a way to generate attention. One of the purposes of the empirical section of this paper will be to provide insights regarding these two mechanisms.

Note that this question leads to a deeper one that has to do with the social production of corporate targets and shaming campaigns (Bartley \& Child, 2014). Even if criticizing is a different activity than running a full-fledged campaign, both might be connected and criticism might in fact be an early stage of private politics that might later lead to full campaigns. So, are criticism and campaigns connected or are they two separate aspects of private politics? The first potential view on this question is that criticism is not strategic, and that the strategic decision-making (targeting) for the activist comes later. Activists would monitor a large pool of environmental and social issues, criticize and then strategically pick those that will become targets in full anticorporate campaigns. In that case, criticism will be mostly about random monitoring of companies, and will not display the types of strategic behaviors highlighted by previous research on private politics. The other view is that monitoring and criticizing firms are already strategic behaviors. As such, there is no such thing as random criticism and criticism is generally the first stage of an anticorporate campaigns.

Understanding this distinction is important for two reasons. First, managers must understand how they need to react to criticism (Lamin \& Zaheer, 2012). If criticism is strategic, then managers need to pay attention to it, even at an early stage and even if the criticism is not very severe. Second, understanding whether criticism is strategic is also important to account for the welfare impact of activism. Activism, in effect, is often presented as an effective counter-power to firms in a globalizing world, in which governments no longer have the ability and authority to supervise questionable corporate practices (Scherer \& Palazzo, 2011). However, if even criticism is strategic, activism will probably be an imperfect way of supporting deficient institutions in identifying environmental and social problems, in that this identification will be skewed toward certain firms in certain places and will leave many others without much surveillance. 
The second limitation of the current literature on private politics is that it does not explore how country or institutional factors might have an impact on the occurrence of public criticism or on its intensity. There are at least two good reasons why these country factors might matter for criticism and private politics in general. On the one hand, if public criticism is strategic, then criticism will likely target firms in countries with higher standards of living and stronger institutions. On the contrary, if criticism were not strategic, but mostly about sheer monitoring to identify issues with corporate practices, then we should expect it to target companies from and in countries with lower standards of living and weaker institutional systems.

This discussion speaks to a broader debate about behavioral changes regarding environmental or social issues. In particular, we should expect to observe importance high impact of institutional factors on Internet/media criticism if hypotheses such as the Environmental Kuznets curve bear some truth. This theory, which has received some empirical support (Stern, Common, \& Barbier, 1996), suggests that people in countries with a certain level of income per capita backed up by the right institutional environment will give higher value to environmental quality and will take actions accordingly. Higher standards of living and stronger institutions should therefore have two effects: (1) push people to take action, become activists themselves and monitor firms' behaviors, and (2) create a fertile ground for public criticism and campaigns against polluting or questionable corporate behaviors. As a result, firms should receive more criticism the higher the standards of living and the stronger the countries' institutions. This would bring support to the idea that human societies might self-regulate over time and find ways to engage in development modes that are more sustainable.

In this paper, we explore these questions by building on a global dataset of CSR-related criticism that includes Internet/media criticism for 451 multinational companies between 2006 and 2009. These companies are incorporated in 26 countries and have been criticized for their operations in 114 countries. We also exploit these institutional variations and explore whether country-level factors contribute to explain why certain firms become private politics targets, and explanations for the intensity of the criticism these companies face.

Our results suggest that criticism is indeed strategic. Activists use mundane Internet/media criticism in a similar way to what has been uncovered by previous literature for large campaigns and boycotts: large and visible companies operating in close-to-consumer (food/beverage; personal goods/textile) and controversial industries (e.g., tobacco; mining) are more likely to be targeted. Moreover, new evidence is provided for 
the importance of country factors: companies that are incorporated in countries of high educational level, environmental attitude, standard of living, and low unemployment rates are preferred targets of $\mathrm{NGO} /$ media activism, which is overall in line with the Environmental Kuznets Curve approach and the idea that activists operate mostly in countries in which there is a favorable audience for their claims.

The remainder of this paper is divided into four parts. In the next section, we explore the differences but also the potential connection between criticism and activist campaigns, and build on these to develop testable hypotheses in the following section. The section "Results" develops the empirical tests. The last section discusses these results and concludes.

\title{
INTERNET/MEDIA CRITICISM AND ACTIVIST CAMPAIGNS
}

\author{
Internet/Media Criticism and Campaigns as Different Aspects of \\ Private Politics
}

In this section, we highlight the differences between campaigns, which has been the main focus of the existing literature, and the more mundane criticism that constitutes the day-to-day activity of many activist organizations. The first difference has to do with the content itself and where it comes from. The theoretical literature on private politics models anticorporate campaigns as a demand by the activist - costly for the firm to implement - associated with a threat of harm and a reward condition if the activist's demand is met (Baron \& Diermeier, 2007). For example, in the Rainforest Action Network case against Citigroup, which started in 2000, the explicit demand by the activist was to get the bank to stop financing activities that could endanger ecosystems. This demand was originally made through a letter sent by the activist organization to Citigroup and stating that: "Citigroup will have to extract itself from unsustainable investments in fossil fuels to move its capital support to renewable energy; they will have to cease funding destruction of primary forest for timber or mining or oil exploration and transition that support to alternative building supplies and paper materials" (Yurday \& Baron, 2004). Internet/media criticism, on the other hand, is generally anonymous, that is, it does not involve a well-identified activist group and articulates neither a concrete demand nor a precise threat. 
In the same way, Internet/media criticism does not call for a precise response from the firm, and its reputational implications are likely to be quite different from campaigns both for the activist and for the firm. For the firm, campaigns can have a highly negative impact on its reputation, which even materializes in drops in share price (King \& Soule, 2007). The opposite is true for activists, who can derive important reputational benefits from successful campaigns, especially in cases in which these activists do not wish to get one firm to concede but rather a whole industry (Baron \& Diermeier, 2007). Internet/media criticism, on the other hand, typically generates lower reputational impact and would probably have to be followed by subsequent steps for concrete reputation loss to take place. Part of the issue here also comes from the fact that criticism has a much lower cost than full-fledged campaigns; a characteristic that could associate them more with "cheap talk," therefore generating a lower direct impact on firms. Table 1 summarizes the key differences between public criticism and activist campaigns.

The conclusion of this analysis is that Internet/media criticism and corporate campaigns have different characteristics, and therefore should not necessarily be expected to display the same characteristics as full activist campaigns do. If corporate targets have been shown to be strategically chosen in previous literature (King \& McDonnell, 2015), criticism could be of different nature. In particular, criticism could be considered to be mostly about random monitoring, with activists thus playing a key role in scanning, identifying, and revealing objectionable behaviors around the world.

Another view, however, could be that criticism and campaigns might be different but related parts of private politics. From that angle, criticism would already be strategic and would support the strategic targeting identified in the previous literature for full-fledged campaigns. We explore this idea in the next section.

Table 1. Public Criticism versus Activist Campaigns.

\begin{tabular}{ll}
\hline Criticism & \multicolumn{1}{c}{ Campaigns } \\
\hline $\begin{array}{l}\text { Generally anonymous } \\
\text { No well-articulated demand }\end{array}$ & Led by a well-identified activist group \\
Lower cost to organize & Includes a specific demand \\
Lower reputation impact both & Higher cost to organize \\
for the firm and the activist & Higher reputation impact both \\
Does not necessarily call for & for the firm and the activist \\
a response by the firm & Calls for a response by the firm \\
\hline
\end{tabular}




\section{Internet/Media Criticism as Early Stage of Activist Campaigns}

There are, in fact, two key theoretical reasons why Internet/media criticism might already be strategic activities and therefore might be directly connected to strategic targeting as in full campaigns. The first reason is that activist organizations have limited attention capabilities (Ocasio, 1997) and therefore need to selectively allocate these attention capabilities. This selection allocation could depend on many different factors associated with the goals of the specific activist organization, but it is reasonable to assume that this allocation follows a targeting approach that is akin to what activists do when they target firms in full campaigns. The second reason to believe that Internet/media criticism is strategic, more fundamental in nature, is that environmental and social issues do not objectively exist but are rather social constructions instrumented by activist organizations (Bartley \& Child, 2014). From this perspective, the key question becomes about the role played by Internet/media criticism in this social construction.

Conceptually, private politics can be considered to work as a chain composed of different stages, with Internet/media criticism being one of the early stages, in which the most attractive issues to pursue are selected, and full-fledged campaigns being the last and triggering open confrontations with firms. ${ }^{1}$ The sequence of the production chain of anticorporate campaigns would thus start with the selection of a type of issue the activist wants to focus on, followed by some media/Internet criticism against targeted firms and potentially ending up with activists fighting a campaign against this firm. This "private politics chain," leading to the production of full-fledged campaigns, is described in Fig. 1.

Assuming that activists behave strategically all along, the first step of campaigns might be the selection of the countries in which to operate. These countries will be the ones in which activists demand are the most likely to be heard and supported by the local population. Similarly, activists will probably select industries that will be the most likely to attract attention. Based on these choices, activists will then pick the best target firms to create attention to their cause, and then will monitor them closely and will criticize them when the opportunity will appear. Among the firms criticized, some will then be targeted with a specific demand and a threat of harm, leading to a full campaign.

Note that considering criticism as an early stage of an activist campaign also fits with the theoretical literature in a different way. In effect, the theoretical literature suggests that both firms and activists have in fact strong incentives to agree on conditions that would avoid a costly campaign for 


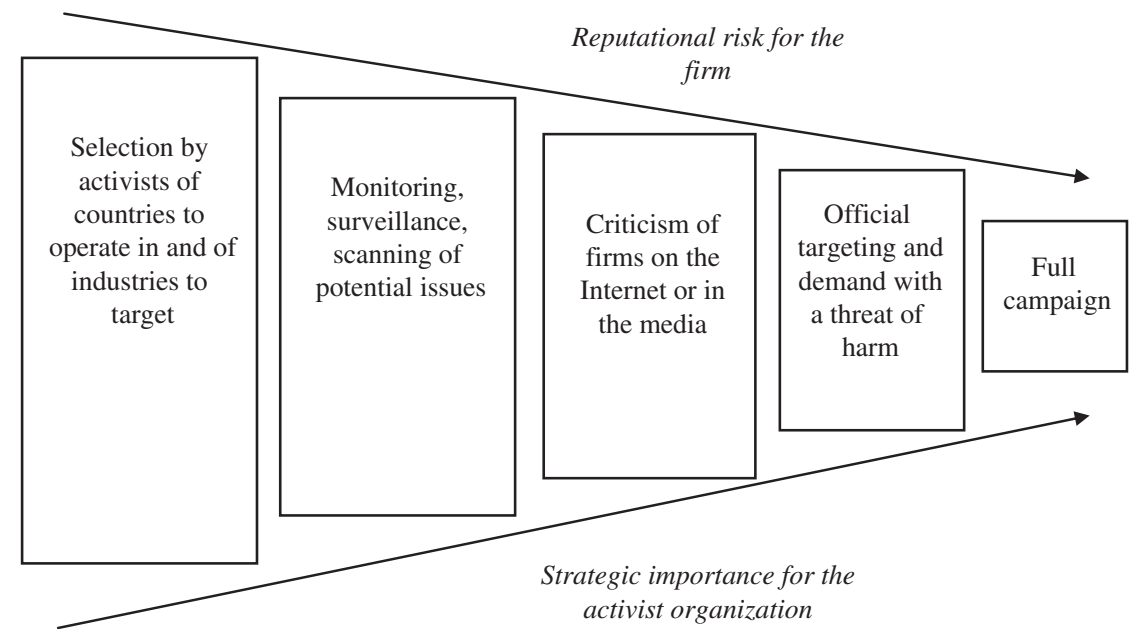

Fig. 1. The Production Chain of Anticorporate Campaigns.

both (Baron \& Diermeier, 2007). In other words, in equilibrium full campaigns should not occur and, in many cases, campaigns should stop early in the production chain described in Fig. 1. On the other hand, criticism should take place and often constitute the first step through which activists create bargaining power in order to negotiate the settlement that will prevent a full campaign. In fact, existing evidence suggests that whereas relatively few full anticorporate campaigns take place, many others could have the potential to be launched. For instance, Wright and Boudet (2012) study different contexts in which campaigns could be expected to take place. They show that only half of them actually do, in spite of problematic environmental issues, organized interests monitoring them and early criticism being voiced.

The implication of this analysis is that Internet/media criticism and full campaigns could be directly connected, in which case they could be driven by a set of similar factors. Another way of considering this is that public criticism is a strategic activity, that is, it would not be about random monitoring but would imply a primary selection of the right targets for activists. If this is the case, then we should expect public criticism to be driven by a similar set of factors to what has been identified in previous literature regarding full campaigns. In what follows, we explore this theory and develop a set of testable hypotheses that will guide our empirical analysis. 


\section{HYPOTHESES}

Based on our concept of private politics production chain, criticism should be driven by country-specific factors, industry factors and firm-specific ones. The last two are actually in line with the existing literature on private politics and firm-activists relationships. Exploring country-specific or institutional factors, on the other hand, is one of the contributions of this paper. We consider them in turn and derive hypotheses that will guide our empirical analysis.

\section{Firm-Specific Factors}

In the context of the production of anticorporate campaigns, activists might first focus their criticism on wealthy firms. Lenox and Eesley (2009) argue that activists selectively target resource-poor firms (low cash flows), as the "cost to an activist to deliver a certain level of harm to a firm, the greater the firm's financial capital" (2009, p. 50). Firms with higher cash flows at their disposal might exert greater corporate opposition as they "are able to support dedicated legal and public relation staff" (ibid.).

Nonetheless, opposite views claim that financially successful firms - that is, wealthy in terms of assets and sales - trigger media attention because they have the resources to meet activists' demands (Yaziji, 2004). Therefore, a wealthy firm can more easily implement the requested changes, under the assumption that it does not employ its resources to "buffer," the activism raised against it. Whether resource-rich or -poor corporations attract Internet/media attention will be left to the empirical analysis.

H1. The wealthier the firm, the higher the likelihood of becoming a target of Internet/media criticism.

Further, it has been argued in the targeting literature that firm "size alone may be a reason why activists target companies" (Graves, Rehbein, \& Waddock, 2001; Rehbein et al., 2004, p. 250). This is based on the general observation that firm size is usually highly correlated with firm visibility, which in turn creates higher media attention for the stakeholder's campaign (Meznar \& Nigh, 1995). Additionally, targeting scholars claim that "[L]arge, visible firms are attractive targets as campaigns against them are more likely to garner attention from the media and the general public" (Lenox \& Eesley, 2009, p. 50). If criticism is strategic, we should therefore expect visible firms to be targeted.

In a similar vein, Baron \& Diermeier posited that companies with "primary and prominent brand(s)" (2007, p. 612) are more likely to be selected 
as activists expect to derive publicity for themselves. Therefore, well-known firms might be preferred targets as contentions with these firms are more "visible" and make the activists themselves better known. The "better known a company is, the juicier the target it makes" (Yaziji, 2004, p. 111; see also Diermeier \& van Mieghem, 2005; Hendry, 2006). Moreover, contributions to social movement theory associate such "potential threats of negative publicity" (Den Hond \& de Bakker, 2007, p. 911) with highly exposed, well-known companies and/or brands. Following this reasoning, we derive the following hypothesis:

H2. The more visible the firm, the higher the likelihood of becoming a target of media/Internet criticism.

Finally, the CSR (i.e., social or environmental) performance of a company has also been discussed as a potential factor that attracts or buffers activist attention. In particular, socially responsible firms might receive more activist attention particularly because of their "emphasis on social responsibility" (Argenti, 2004, p. 111). Since firms are "thought to be sympathetic" (Baron \& Diermeier, 2007, p. 612), that is more receptive to social and environmental concerns, such "truly socially responsible companies" (Argenti, 2004, p. 111) are more likely to become targeted (King \& McDonnell, 2015). In this vein, it has been further argued that good "corporate students" are evaluated more strictly in such a way that they keep up their good performance. Luo, Meier, and Oberholzer-Gee (2010) suggest that the media are more likely to report on corporate "environmental sins" if target firms indicate better environmental records, and provide higher degrees of CSR transparency (disclosure of environmental performance data). If criticism is strategic, firms that have presented themselves as CSR-oriented firms could therefore be attractive targets for activists.

H3. Companies that are perceived as more socially/environmentally responsible are less likely to be targeted by Internet/media criticism.

\section{Industry Factors}

In the context of the production chain of anticorporate campaigns presented in Fig. 1, activists should be expected to pick firms in industries that might be well known from the public and that can be easily associated to questionable behaviors. Yaziji (2004), for instance, posits that companies are particularly exposed to external criticism if they sell unhealthy products (tobacco, alcoholic beverages), offer dangerous services (gambling, pornography), or even produce dangerous goods (weapons, nuclear energy). Studies on corporate 
reputation emphasize the inherent dangers to which a high-reputation firm is exposed if it operates in a per se relatively controversially perceived industry (see Barnett \& Hoffmann, 2008).

As indicated previously, Rehbein et al. (2004) provide evidence for such industry-affiliation claims. They find that operating in industries that are likely to "produce negative contingencies" (p. 249) provokes NGO/media attention. King and Soule (2007), as well as King (2008), provide further empirical evidence that supports this believed causality between industrial controversy and stakeholder activism. Similar to full campaigns, activists might thus pick targets in industries that will easily generate interest and support from the public.

H4. Companies that operate in controversially perceived industries are more likely to be targeted by Internet/media criticism.

Similarly, high consumer exposure (Weber \& Marley, 2012), that is operating close to final customers, may increase the targeting likelihood (Bartley \& Child, 2014). Baron and Diermeier (2007) reason that it "may be relatively low cost for an activist" (p. 614) to damage the reputation of a "consumer product company (...) whereas harming an industrial products company may be quite costly" (ibid.). This argument is not only explained by higher customer visibility. In fact, it has also been associated with the existence of substitute products. For example, the boycott against Shell's Brent Spar oilrig in 1995 was highly successful for Greenpeace because final consumers, who followed the NGO's boycott call, incurred comparatively low switching costs by "easily" getting fuel elsewhere (see Diermeier \& van Mieghem, 2005). Resource-dependence theory explains such stakeholder movements according to which consumers can successfully withhold resources from a firm if they possess power (e.g., knowledge) over this company (Pfeffer \& Salancik, 1978). This is the case for corporations whose products are close to the final consumer. Thus, if criticism is strategic, we hypothesize that:

H5. Companies that operate in "close-to-consumer" industries are more likely to be targeted by Internet/media criticism.

\section{Country-Specific and Institutional Factors}

Country-specific and institutional factors have not been considered yet in the private politics literature. Yet, they should have an impact and could 
help identify whether criticism are driven by strategic intent or by sheer monitoring. Within the production chain of anticorporate campaigns, activists are likely to issue criticism against firms from countries in which the population will be sympathetic to the cause that these activists want to defend. Previous literature suggests, in fact, that the level of intensity and severity of activists or NGOs criticism vary across countries (Wapner, 2009). A firm like Nestlé from Switzerland, for instance, has been much more criticized for using palm oil than one of its large rival, Unilever, from the United Kingdom. Doh and Guay claim that activists search for particular "access points" (2006, p. 52) per country due to national particularities. Additionally, Diermeier and van Mieghem (2005), with regard to the Brent Spar case, illustrated how Greenpeace chose not to target Shell Plc. in England, but instead concentrated its activism on Shell's German subsidiary because Germany was deemed more receptive and sensible to environmental concerns.

Socioeconomic conditions have also been shown to matter to influence citizens' attitudes toward firms, toward corporate social responsibility activities, and toward the potential need for self-regulation (Matten \& Moon, 2008). In that spirit, socioeconomic conditions that structurally shape behaviors, for instance, through a country's level of education or its employment rate (Beck \& Levine, 2005; La Porta, Lopez-de-Silanes, Shleifer, \& Vishny, 1998, 2000) should matter in the context of activists' targeting decisions. Firms incorporated in a country with a high level of education could be more strictly scrutinized than companies incorporated in countries where citizens are less knowledgeable and aware of social and environmental issues.

The literature on sustainable development and growth also supports the idea that individuals in a society should display a higher willingness to pay for better environmental conditions and cleaner air the higher the standard of living in the country. In particular, the Environmental Kuznets curve theory argues that environmental degradation first increase with income and then reaches a threshold after which environmental degradation decreases with income (Stern et al., 1996). The factors driving this inverted-U relationship between per capita income and pollution are generally considered to be related to the evolution from industry-oriented economies to more information-intensive and service-oriented ones, as well as to a higher environmental awareness, stronger environmental regulations and more advanced green technologies. However, in addition to these factors, a stronger scrutiny on business practices and more pressure on polluting firms should also take place, once the income threshold has been reached, 
in order for the downward part of the curve to emerge. From this perspective, companies incorporated in countries with higher standard of living should also be criticized more often and more intensely than companies incorporated in countries that have not reached that threshold.

Similarly, other measures of a country's wealth such as the unemployment level of unemployment or a country's level of education should be associated with a higher level of activism and therefore more criticism against firms.

H6. The better the socioeconomic situation of a country, the higher the likelihood for firms incorporated in that country to be targeted by Internet/media criticism.

Second, institutional characteristics might matter as well. More democratic and less corrupt institutions create plenty of opportunities for outside parties to voice their concerns not only about what government officials are doing but also about what firms and managers do (Dyck \& Zingales, 2002). Institutions include "constitutions, laws, policies, [hence] any formal agreements" (Doh \& Guay, 2006, p. 52) that are (formally) set up in the national context to "provide the background conditions against which the actions of individuals and associations take place" (ibid.; see also Jones, 1999). The stakeholder literature has emphasized, albeit without much real empirical analysis, the variation across national political environments. Doh and Guay (2006) and De Bakker and den Hond (2008), for instance, highlight such governmental variance, notably between Europe and the United States, by referring to: "the opposition of several European countries to the marketing of genetically modified crops and food in Europe; the insistence of US-firms and Government to enforce patent protection for Aids/HIV medication in developing countries; as well as the differing national commitments to CO2-emission reductions of the Kyoto Protocol" (ibid.).

Institutions favoring a strong governance and control over government officials, for instance, through less corruption and more democracy, should also offer more opportunities for activists to voice their concerns and criticize business practices. As governments seem to influence companies in their behaviors and decisions, they might also influence activists in their targeting strategies. Therefore, favorable country contexts might actively encourage stakeholder activism and strategic criticism for firms for certain countries (see, e.g., Jones, 1999).

H7. The less corrupt and more democratic the institutions of a country, the higher the likelihood for firms incorporated in that country to become targeted by Internet/media criticism. 


\section{DATA AND METHODS}

To explore our hypotheses empirically, we built a unique dataset of firms that were exposed to CSR-related criticism from 2006 to 2009. The firm sample consists of the world's most admired firms, annually ascertained by Fortune. To become eligible, corporations must surpass $\$ 10$ billion in revenue and rank among the largest firms within their industry peers (by revenue). We chose this sample as the firms included are typically large multinationals, which exposes them to various different sociocultural contexts and stakeholder scrutiny. Data for these firms are also relatively easy to access. The Fortune survey for the period 2006-2009 contains 642 companies, which have been part of the ranking at least once, and we obtained detailed data for 451 of them. We matched this sample with another database covering Internet/media criticism. The database on CSR-related criticism was, in its original form, provided by the Swiss-based consultancy Reprisk, whose mission is to capture the impact of external factors on a firm's reputation. It includes criticism information collected for many firms part of the ranking since 2006. Each firm-specific criticism contains detailed information about the content, initiator, date, and location of the reported stakeholder action, as well as its level of severity.

We tried to make sure that our database contained only criticism, and not other stages of the campaigns production chain in two ways. First, we considered only the first criticism and avoided any further one, or any escalation of the same criticism: once a criticism has been made, it is not considered a second time in our data. Second, we looked at all the criticism one by one and excluded the ones that were referring to larger actions such as boycotts or organized actions.

The constructed panel dataset merges the data on firms and criticism exposure for the 2006-2009 period, and comprises 8,054 Internet and media criticism observations for the Fortune-rated companies. Criticism is considered from a large number of different sources (both Internet and media sources) expressed in nine languages. ${ }^{2}$ The collapsed dataset generates 1,419 firm-level observations once missing data are taken into account. This results in 4.7 criticisms per firm and year on average (see Table 2), but with significant variations across firms; some firms being criticized often and others hardly or never. Further, the severity of each criticism, as evaluated by Reprisk, varies between three degrees (1-3, see Fig. 2), with a value of 1 indicating light criticism (e.g., the firm being criticized for being slow at issuing an environmental report), whereas 3 indicates very severe criticism for the company reputation (e.g., the firm 
being accused of jeopardizing customers' health). These different levels of severity are coded for each criticism reported by two independent analysts of the consultancy, based on several predefined criteria that determine the extent and severity of the accusation. Tables 2 and 3, as well as Figs. 2 and 3 , provide a description of the criticism included in our database: per industry, per country, number of criticism and severity.

\section{Dependent Variable(s)}

Because our empirical approach is exploratory, we consider different estimation methods using both the firm sample and the criticism samples. First, we look at the probability of a firm being criticized in our sample, and consider probit models in which the dependent variable takes a value of 1 if a firm has been criticized in a given year. Second, we take a first look at the intensity of the criticism and consider whether there are differences in the factors that lead firms to be targeted by severe criticism,

Table 2. Number of Criticisms Collected 2006-2009.

\begin{tabular}{lcccc}
\hline Variable/Year & 2006 & 2007 & 2008 & 2009 \\
\hline Number of criticisms p.a. (TCQ) & $604^{\mathrm{a}}$ & 1,657 & 3,269 & 2,524 \\
Number of firms included in the criticism database & 451 & 451 & 451 & 451 \\
Average number of criticisms per firm & 1.34 & 3.67 & 7.25 & 5.60 \\
\hline
\end{tabular}

${ }^{a}$ The database for CSR criticism was only established in 2006; this explains the fewer number of firm-criticism observations for 2006, provided in Tables 1 and 2.

Table 3. Number of Criticism per Country of Origin of the Firms.

\begin{tabular}{llll}
\hline Country & Total & Country & Total \\
\hline USA & 3,741 & Australia & 128 \\
UK & 1,043 & Others & 121 \\
Germany & 777 & Brazil & 86 \\
France & 541 & Luxembourg & 84 \\
Netherland & 486 & Russia & 84 \\
Switzerland & 419 & Canada & 70 \\
Japan & 318 & Finland & 66 \\
China & 185 & Italy & 66 \\
Korea & 154 & Belgium & 52 \\
Spain & 136 & Indonesia & 41 \\
\hline
\end{tabular}




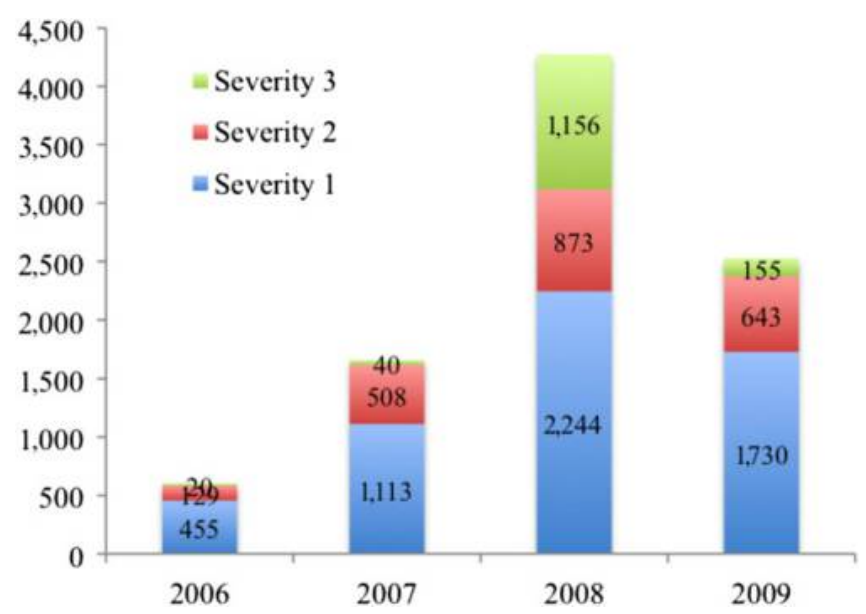

Fig. 2. Number and Severity Levels of Corporate Criticisms.

instead of the overall criticism. We therefore compute a binary outcome variable ("severe criticism") that indicates whether a company has been exposed to severe stakeholder activism (categories 2 and 3 in our data) over a year. Again, we just use simple probit models. Third, we move from the firm level to the criticism level and create an ordinal-dependent variable that includes all four possible different levels of harm/critique a corporation can be exposed to: from zero (i.e., zero harm or no criticism) to 3 , with 3 being the most severe level of criticism activity. We then use ordered probit to explore the drivers for the intensity of criticism. For all these models, we include year dummies and compute robust standard errors by clustering at the firm level.

\section{Independent Variables}

\section{Firm-Level Variables}

To test the hypotheses $\mathrm{H} 1-\mathrm{H} 4$ assessing the influence of corporate factors on critique exposure, we first estimate the influence of financial dimensions: firm assets, considered in logarithm to account for skewness, and cash flow, as proxies of resource-richness. To account for firm profitability, we further include Return on assets (ROA). Sales - also in logarithm - are inserted 


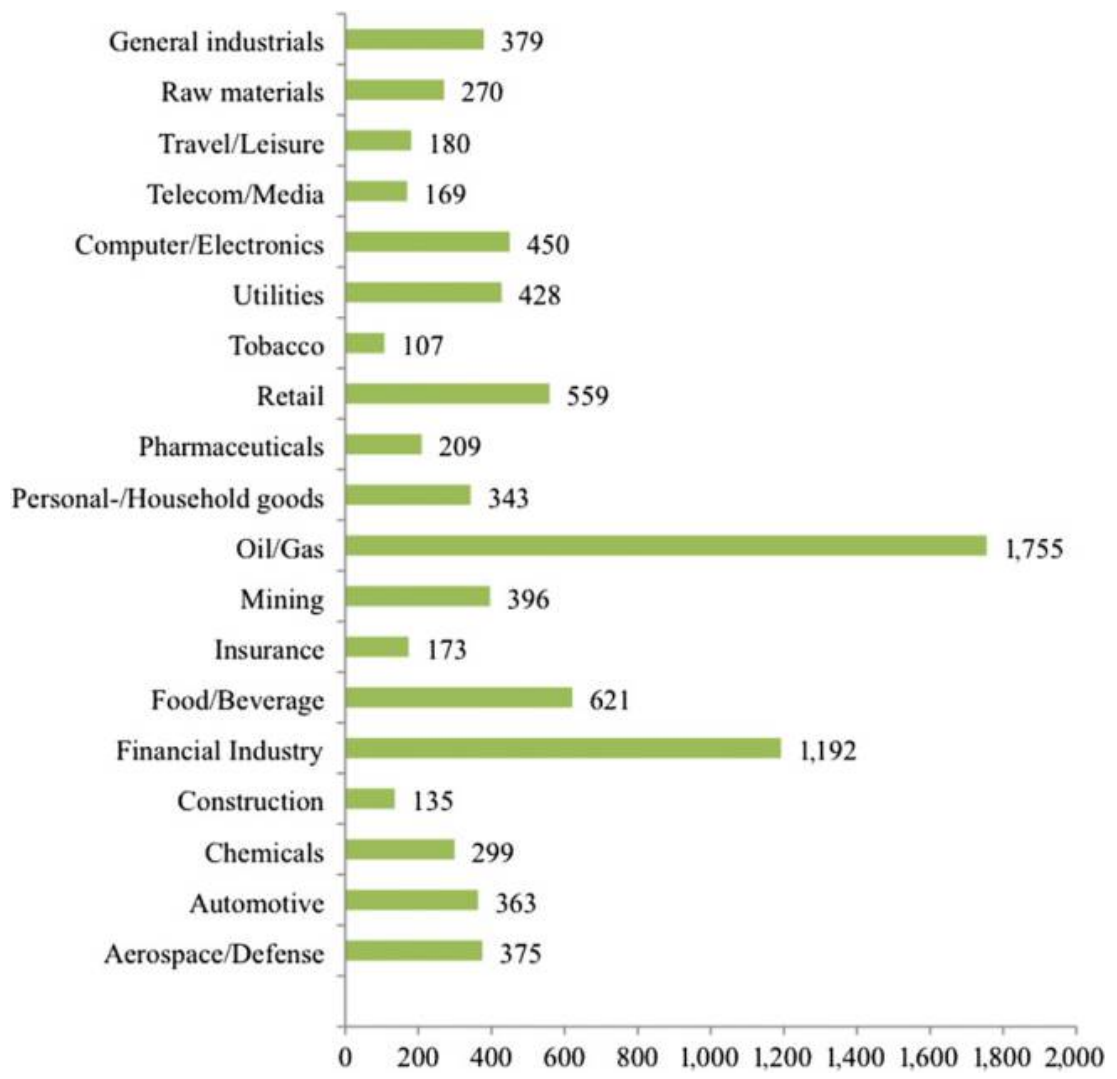

Fig. 3. Number of Criticisms per Industry.

as a measure of firm size. All financial data were obtained from ThomsonDatastream and, for the sake of comparability, considered in logs. To approximate firm visibility in terms of brand awareness, we compute another binary variable that indicates whether a firm possesses top brands (annually ranked by Interbrand) ${ }^{3}$ in its corporate portfolio. The absolute brand values were not included because of insufficient data.

With regard to variables regarding a firm's CSR performance (as hypothesized in $\mathrm{H} 4$ ), we include a binary variable that distinguishes companies that belong to the Dow Jones Sustainability Index (DJSI). ${ }^{4} \mathrm{As}$ an approximated measure of ecological/environmental performance, we construct a dummy variable that indicates whether the firm disclosed its 
carbon footprint (proxied by the data from the carbon disclosure project, CDP). ${ }^{5}$ Absolute scores were not taken into consideration as they would have restrained the estimation sample significantly. We finally compute a binary variable that controls whether a company is publicly listed.

\section{Industry-Level Variables}

To identify industry-specific effects, as hypothesized in $\mathrm{H} 5$, we compute dummy variables for each industry sector based on the sector-classification of the criticism database.

\section{Country-Level Variables}

To evaluate whether an NGO/media's firm selection depends on the particularities of the country in which the firm is established, we inserted variables that mirror the (institutional) quality of a country as well as its socioeconomic situation following measures used in previous studies (see, e.g., Gallup, Sachs, \& Mellinger, 1999; Kaufmann, Kraay, \& Mastruzzi, 2011; Sachs, 2003).

First, to estimate the influence of socioeconomic factors as hypothesized in H6, we include the GDP (Gross Domestic Product) - annual growth rate per capita - and the country's annual unemployment rate as economic measures. To account for sociological factors, we insert a country's education index, as well as an indicator of its standard of living. The data for all three variables was obtained from the United Nations' Development Program (UNDP) database. ${ }^{6}$ Further, to take into account the growing importance of environmental awareness in many nation-states (Halme \& Huse, 1997; Philippe \& Durand, 2011), we also include a measure indicating a country's environmental consciousness, proxied by the environmental performance index (EPI). ${ }^{7}$

Second, to capture the effects of institutional factors as hypothesized in H7, we include governance indices that constitute approved proxies for indicating a country's institutional quality (see, e.g., Kaufmann et al., 2011; Sachs, 2003). Such governance data was obtained from the Worldwide Governance Indicators (WGI) project. ${ }^{8}$ Therefore, we consider four variables: Voice and accountability indicates to what extent "a country's citizens are able to participate in selecting their government, as well as freedom of expression, freedom of association, and a free media" (Kaufmann, Kraay, \& Mastruzzi, 2009, p. 6). Political stability "measures the perceptions of the likelihood that the government will be destabilized or overthrown by unconstitutional or violent means, including domestic violence and terrorism" (ibid.). Finally, control of corruption mirrors "perceptions of the extent to 
which public power is exercised for private gain, including both petty and grand forms of corruption, as well as "capture" of the state by elites and private interests" (ibid.).

\section{RESULTS}

Table 4 presents descriptive statistics and pairwise correlations. Results of our empirical investigation are provided in Table 5. We first discuss the results of the targeting likelihood estimations (Models 1-2), and then move to explore the determinants of criticism intensity (Model 3).

\section{Results for Model 1 - General Criticism Sample}

In the first column of Table 5, we estimate the likelihood that firms will become a target of Internet/media criticism. Among the corporate factors, the two variables signaling firm size and visibility - sales and brand awareness - have a significant impact on the targeting likelihood, providing support to H2. Likewise, for stock-listed corporations, belonging to the DJSI increases the targeting likelihood (supporting H3). This implies that corporations with a stronger CSR orientation are more likely to be targeted, a result that is in line with what was found by Luo et al. (2010) regarding media coverage of oil spills. These first results are strongly in line with the idea that Internet/media criticism is already a strategic stage, that is, that activists pick the corporate targets that are the most likely to attract attention to their cause.

With regard to industry effects, service industries such as travel/leisure, insurance/banking, telecom, and media particularly reduce the targeting likelihood. This is in line with the argument that service industries are perceived as less polluting industries than those of the manufacturing sectors (see, e.g., Cole, 2000). Interestingly, low statistical support could be provided for $\mathrm{H} 4$ and $\mathrm{H} 5$ : among the controversial industries, only Mining is more likely to be targeted, and traditional B2C sectors, for example, Food and beverage or Automotive, do not seem to affect the targeting likelihood either.

Regarding country effects, our results suggest, on the one hand, that the targeting likelihood is high for firms incorporated in countries for which institutions are less stable and democratic. The coefficients of voice/accountability and political stability as proxies of political/institutional influence $(\mathrm{H} 7)$ 
Table 4. Descriptive Statistics and Correlation.

\begin{tabular}{|c|c|c|c|c|c|c|c|c|c|c|c|c|c|c|c|c|c|c|c|c|}
\hline & Mean & S.D. & Criticism & $\begin{array}{l}\text { Criticism } \\
\text { Intensity }\end{array}$ & $\begin{array}{l}\text { Cash } \\
\text { flow }\end{array}$ & ROA & Sales & Assets & DJSI & $\begin{array}{l}\text { Envt. } \\
\text { Disclos. }\end{array}$ & Notlisted & $\begin{array}{l}\text { Top } \\
\text { Brand }\end{array}$ & $\begin{array}{l}\text { GDP } \\
\text { Growth }\end{array}$ & Unemployment & $\begin{array}{c}\text { Life } \\
\text { Quality }\end{array}$ & Educ. & $\begin{array}{l}\text { Envt. } \\
\text { Consc. }\end{array}$ & $\begin{array}{c}\text { Voice } \\
\text { Account }\end{array}$ & $\begin{array}{l}\text { Pol. } \\
\text { Stab. }\end{array}$ & Anticorrupt \\
\hline Criticism & 0.72 & 0.23 & & & & & & & & & & & & & & & & & & \\
\hline $\begin{array}{l}\text { Criticism } \\
\text { Intensity }\end{array}$ & 1.36 & 0.37 & & 1.00 & & & & & & & & & & & & & & & & \\
\hline Cash flow & 8.52 & 3.08 & 0.07 & 0.12 & 1.00 & & & & & & & & & & & & & & & \\
\hline ROA & 0.06 & 0.02 & 0.03 & 0.05 & 0.23 & 1.00 & & & & & & & & & & & & & & \\
\hline Ln Sales & 17.8 & 12.05 & 0.29 & 0.32 & 0.24 & 0.10 & 1.00 & & & & & & & & & & & & & \\
\hline Ln Assets & 10.2 & 5.3 & 0.24 & 0.26 & 0.00 & -0.12 & 0.67 & 1.00 & & & & & & & & & & & & \\
\hline DJSI & 0.51 & 0.12 & 0.01 & 0.02 & 0.02 & -0.02 & 0.07 & 0.12 & 1.00 & & & & & & & & & & & \\
\hline Envt. Disclo. & 0.69 & 0.53 & 0.25 & 0.27 & 0.11 & 0.11 & 0.45 & 0.42 & 0.15 & 1.00 & & & & & & & & & & \\
\hline Notlisted & 0.04 & 0.08 & -0.15 & -0.12 & -0.06 & 0.00 & -0.15 & -0.17 & -0.05 & -0.31 & 1.00 & & & & & & & & & \\
\hline Top Brand & 70.3 & 0.18 & 0.04 & 0.07 & -0.02 & 0.00 & 0.14 & 0.16 & 0.03 & 0.09 & -0.10 & 1.00 & & & & & & & & \\
\hline GDP Growth & 1.45 & 0.89 & 0.04 & 0.05 & 0.05 & 0.07 & -0.01 & -0.02 & -0.15 & -0.18 & 0.19 & 0.07 & 1.00 & & & & & & & \\
\hline Unemployment & 4.61 & 0.95 & 0.08 & 0.04 & 0.14 & -0.06 & 0.18 & 0.25 & 0.30 & 0.10 & -0.06 & -0.03 & -0.07 & 1.00 & & & & & & \\
\hline Life Quality & 77.4 & 0.48 & -0.04 & -0.05 & -0.06 & 0.07 & -0.03 & -0.06 & -0.02 & 0.08 & -0.18 & -0.01 & -0.43 & -0.25 & 1.00 & & & & & \\
\hline Education & 77.2 & 0.18 & 0.03 & 0.04 & -0.07 & -0.01 & -0.10 & -0.14 & -0.11 & 0.05 & -0.06 & -0.03 & -0.31 & -0.43 & 0.50 & 1.00 & & & & \\
\hline Envt. Consc. & 81.9 & 0.26 & 0.10 & 0.12 & 0.04 & -0.06 & 0.07 & 0.14 & 0.25 & 0.20 & -0.21 & -0.05 & -0.57 & 0.33 & 0.18 & 0.02 & 1.00 & & & \\
\hline Voice Account & 85.7 & 0.17 & -0.06 & -0.04 & 0.04 & 0.01 & 0.09 & 0.11 & 0.27 & 0.31 & -0.24 & -0.11 & -0.73 & 0.25 & 0.55 & 0.24 & 0.51 & 1.00 & & \\
\hline Pol. Stab. & 66.4 & 0.75 & -0.02 & -0.05 & 0.01 & -0.05 & 0.08 & 0.07 & 0.27 & 0.18 & -0.12 & -0.04 & -0.36 & 0.22 & 0.32 & 0.21 & 0.43 & 0.53 & 1.00 & \\
\hline Anticorrupt & 87.4 & 0.34 & 0.04 & 0.05 & -0.02 & -0.04 & 0.05 & 0.05 & 0.25 & 0.27 & -0.18 & -0.09 & -0.66 & 0.08 & 0.57 & 0.28 & 0.52 & 0.59 & 0.52 & 1.00 \\
\hline
\end{tabular}

First column (Criticism): Firm sample, $n=1,419$; Other columns: Full issue sample, $n=8,054$ 
Table 5. Likelihood of a Firm Being Targeted.

\begin{tabular}{|c|c|c|c|}
\hline Variables & $\begin{array}{c}\text { Probit Model (1) } \\
\text { General criticism } \\
\text { Probit }\end{array}$ & $\begin{array}{c}\text { Probit Model (2) } \\
\text { Severe criticism } \\
\text { Probit }\end{array}$ & $\begin{array}{l}\text { Model (3) } \\
\text { Criticism intensity } \\
\text { Ordered probit }\end{array}$ \\
\hline \multicolumn{4}{|l|}{ Corporate influence } \\
\hline Ln cash flow & $\begin{array}{c}-0.025 \\
(0.0698)\end{array}$ & $\begin{array}{c}0.045 \\
(0.082)\end{array}$ & $\begin{array}{c}0.0380 \\
(0.054)\end{array}$ \\
\hline ROA (return on assets) & $\begin{array}{c}-0.310 \\
(0.878)\end{array}$ & $\begin{array}{c}-0.137 \\
(0.930)\end{array}$ & $\begin{array}{c}-0.710 \\
(0.841)\end{array}$ \\
\hline Ln sales & $\begin{array}{l}0.471^{* * *} \\
(0.099)\end{array}$ & $\begin{array}{c}0.359^{*} \\
(0.101)\end{array}$ & $\begin{array}{l}0.401 * * * \\
(0.075)\end{array}$ \\
\hline Ln assets & $\begin{array}{c}0.066 \\
(0.096)\end{array}$ & $\begin{array}{l}0.211^{*} \\
(0.114)\end{array}$ & $\begin{array}{c}0.054 \\
(0.072)\end{array}$ \\
\hline Social performance (DJSI) & $\begin{array}{c}0.180^{*} \\
(0.112)\end{array}$ & $\begin{array}{c}0.152 \\
(0.189)\end{array}$ & $\begin{array}{c}0.099 \\
(0.175)\end{array}$ \\
\hline Environmental disclosure & $\begin{array}{c}0.0170 \\
(0.120)\end{array}$ & $\begin{array}{c}0.120 \\
(0.119)\end{array}$ & $\begin{array}{c}0.130 \\
(0.085)\end{array}$ \\
\hline Nonpublic listed dummy & $\begin{array}{c}-1.007 \\
(1.224)\end{array}$ & $\begin{array}{c}-1.196 \\
(1.404)\end{array}$ & $\begin{array}{r}-1.047 \\
(1.359)\end{array}$ \\
\hline Top brand dummy & $\begin{array}{l}0.655^{* * * *} \\
(0.128)\end{array}$ & $\begin{array}{l}0.240^{* *} \\
(0.099)\end{array}$ & $\begin{array}{l}0.337^{* * * *} \\
(0.083)\end{array}$ \\
\hline \multicolumn{4}{|l|}{ Country/institutional factors } \\
\hline GDP growth rate per capita & $\begin{array}{c}0.0221 \\
(0.051)\end{array}$ & $\begin{array}{l}0.020 \\
(0.077)\end{array}$ & $\begin{array}{l}0.067^{*} \\
(0.029)\end{array}$ \\
\hline Unemployment & $\begin{array}{c}-0.160 \\
(0.193)\end{array}$ & $\begin{array}{c}-0.279^{* * * *} \\
(0.451)\end{array}$ & $\begin{array}{c}-0.011 \\
(0.009)\end{array}$ \\
\hline Life quality & $\begin{array}{c}-0.055^{* *} \\
(0.0242)\end{array}$ & $\begin{array}{c}-0.029 \\
(0.026)\end{array}$ & $\begin{array}{c}-0.022 * * * \\
(0.0072)\end{array}$ \\
\hline Level of education & $\begin{array}{c}-0.010 \\
(0.041)\end{array}$ & $\begin{array}{l}0.284^{* * *} \\
(0.072)\end{array}$ & $\begin{array}{c}0.058^{*} \\
(0.003)\end{array}$ \\
\hline Environmental consciousness & $\begin{array}{l}0.143^{* * * *} \\
(0.035)\end{array}$ & $\begin{array}{l}0.061^{* *} \\
(0.029)\end{array}$ & $\begin{array}{l}0.042 * * * \\
(0.013)\end{array}$ \\
\hline Voice and accountability & $\begin{array}{r}-0.081^{* *} \\
(0.0375)\end{array}$ & $\begin{array}{c}-0.191^{* * *} \\
(0.068)\end{array}$ & $\begin{array}{c}-0.0028 \\
(0.0082)\end{array}$ \\
\hline Political stability & $\begin{array}{c}-0.0355^{*} \\
(0.022)\end{array}$ & $\begin{array}{c}-0.008 \\
(0.028)\end{array}$ & $\begin{array}{c}-0.022 * * * \\
(0.0036)\end{array}$ \\
\hline Control of corruption & $\begin{array}{l}0.101^{* * *} \\
(0.032)\end{array}$ & $\begin{array}{l}0.081^{* *} \\
(0.044)\end{array}$ & $\begin{array}{l}0.0171^{*} \\
(0.008)\end{array}$ \\
\hline Industry influence & & & \\
\hline
\end{tabular}

\begin{tabular}{lccc}
\hline Aerospace/defense & -0.490 & 0.312 & $-1.092^{* *}$ \\
Automotive & $(0.577)$ & $(0.355)$ & $(0.527)$ \\
& -0.302 & $1.508^{*}$ & $0.720^{*}$ \\
Chemicals & $(0.371)$ & $(0.692)$ & $(0.376)$ \\
& -0.555 & 0.011 & $1.052^{* *}$ \\
& $(0.689)$ & $(0.422)$ & $(0.529)$
\end{tabular}


Table 5. (Continued)

\begin{tabular}{|c|c|c|c|}
\hline Variables & $\begin{array}{l}\text { Probit Model (1) } \\
\text { General criticism } \\
\text { Probit }\end{array}$ & $\begin{array}{l}\text { Probit Model (2) } \\
\text { Severe criticism } \\
\text { Probit }\end{array}$ & $\begin{array}{c}\text { Model (3) } \\
\text { Criticism intensity } \\
\text { Ordered probit }\end{array}$ \\
\hline Construction & $\begin{array}{l}-0.90 \\
(0.575)\end{array}$ & $\begin{array}{c}-1.112^{* *} \\
(0.488)\end{array}$ & $\begin{array}{l}-1.398^{* * *} \\
(0.527)\end{array}$ \\
\hline Financial industry & $\begin{array}{c}-1.098^{*} \\
(0.610)\end{array}$ & $\begin{array}{c}-1.428^{* *} \\
(0.644)\end{array}$ & $\begin{array}{c}-1.366^{* *} \\
(0.571)\end{array}$ \\
\hline Food/beverage & $\begin{array}{c}0.0833 \\
(0.362)\end{array}$ & $\begin{array}{l}1.677^{* *} \\
(0.712)\end{array}$ & $\begin{array}{l}1.181^{* *} \\
(0.343)\end{array}$ \\
\hline Insurance & $\begin{array}{c}-1.429 * * \\
(0.609)\end{array}$ & $\begin{array}{c}-1.326^{* * * *} \\
(0.279)\end{array}$ & $\begin{array}{c}-1.978 * * * \\
(0.579)\end{array}$ \\
\hline Mining & $\begin{array}{l}1.126^{* *} \\
(0.402)\end{array}$ & $\begin{array}{l}1.241^{* *} \\
(0.474)\end{array}$ & $\begin{array}{l}1.211^{*} \\
(0.544)\end{array}$ \\
\hline Oil/gas & $\begin{array}{c}-0.528 \\
(0.599)\end{array}$ & $\begin{array}{c}0.367 \\
(0.389)\end{array}$ & $\begin{array}{r}0.942 * \\
(0.521)\end{array}$ \\
\hline Personal-/household goods & $\begin{array}{c}-0.232 \\
(0.356)\end{array}$ & $\begin{array}{l}1.478^{* *} \\
(0.752)\end{array}$ & $\begin{array}{c}0.419 \\
(0.557)\end{array}$ \\
\hline Pharmaceuticals & $\begin{array}{c}-0.390 \\
(0.355)\end{array}$ & $\begin{array}{c}-0.590 \\
(0.665)\end{array}$ & $\begin{array}{c}-0.397 \\
(0.429)\end{array}$ \\
\hline Retail & $\begin{array}{c}-1.002^{* * * *} \\
(0.359)\end{array}$ & $\begin{array}{c}-1.101^{* *} \\
(0.347)\end{array}$ & $\begin{array}{c}-0.893^{* *} \\
(0.406)\end{array}$ \\
\hline Tobacco & $\begin{array}{c}0.345 \\
(0.658)\end{array}$ & $\begin{array}{l}1.901 * * \\
(0.788)\end{array}$ & $\begin{array}{l}1.131^{*} \\
(0.272)\end{array}$ \\
\hline Utilities & $\begin{array}{c}-0.399 \\
(0.555)\end{array}$ & $\begin{array}{c}-0.417 \\
(0.525)\end{array}$ & $\begin{array}{l}1.058^{* *} \\
(0.518)\end{array}$ \\
\hline Computer/electronics & $\begin{array}{c}-0.371 \\
(0.367)\end{array}$ & $\begin{array}{c}1.053 \\
(0.678)\end{array}$ & $\begin{array}{c}-0.619 \\
(0.489)\end{array}$ \\
\hline Telecom/media & $\begin{array}{c}-1.402 * * * \\
(0.360)\end{array}$ & $\begin{array}{c}-1.634 * * * \\
(0.377)\end{array}$ & $\begin{array}{c}-1.632 * * * \\
(0.370)\end{array}$ \\
\hline Travel/leisure & $\begin{array}{c}-0.800^{* *} \\
(0.361)\end{array}$ & $\begin{array}{c}-1.112 \\
(0.373)\end{array}$ & $\begin{array}{c}-1.033^{* * * *} \\
(0.411)\end{array}$ \\
\hline Raw materials & $\begin{array}{c}-0.555 \\
(0.572)\end{array}$ & $\begin{array}{c}-1.283^{* *} \\
(0.552)\end{array}$ & $\begin{array}{c}-1.027 * * \\
(0.510)\end{array}$ \\
\hline General industrials & $\begin{array}{c}-1.165^{* *} \\
(0.558)\end{array}$ & $\begin{array}{c}-1.751^{* * *} \\
(0.563)\end{array}$ & $\begin{array}{l}1.541^{* * * *} \\
(0.566)\end{array}$ \\
\hline Constant & $\begin{array}{c}-12.82^{* * *} \\
\quad(4.122)\end{array}$ & $\begin{array}{c}-9.48^{* * *} \\
(4.553)\end{array}$ & $\begin{array}{l}\text { Cut1 } 6.287^{* * *} \\
\text { Cut2 } 7.016^{* * *} \\
\text { Cut3 } 9.863^{* * *}\end{array}$ \\
\hline Year dummies & Yes & Yes & Yes \\
\hline Wald $\mathrm{Chi}^{2}$ & $306.62^{* * *}$ & $238.94^{* * *}$ & $206.71^{* * *}$ \\
\hline Pseudo $R^{2}$ & $21 \%$ & $25 \%$ & $19 \%$ \\
\hline Observations & 1,419 & 1,419 & 8,054 \\
\hline
\end{tabular}

Robust standard errors in parentheses.

${ }^{* * *} p<0.01, * * p<0.05, * p<0.1$. 
are both negative and significant. These results are further supported by the socioeconomic influence factors hypothesized in H6: firms incorporated in countries of low-living standards are preferred targets. Together, these results do not support the idea of strategic criticism and would rather suggest that a part of activists' behaviors is about monitoring of corporate issues for firms from countries in which issues are likely to occur.

On the other hand, evidence is also provided for superior country variables. Companies that are incorporated in countries of high environmental consciousness (H6) attract unwanted $\mathrm{NGO} /$ media attention. This finding is endorsed by the corruption indicator, a further measure of institutional quality (H7): the better a firm's home-country controls corruption, the higher the company's targeting likelihood becomes. These results on environmental consciousness and control of corruption are in line with what we would expect if activists select firms from countries that are positioned "high up" in the Environmental Kuznets Curve.

Overall, these results are thus somewhat two-sided and seem to suggest that activists adopt complementary targeting behaviors. They talk to a certain audience by targeting large firms in countries in which CSR is perceived important. However, activists also play a monitoring role and uncover dubious behaviors for firms from countries in which institutions are weak.

With regard to the actual strength of the effects, the estimated coefficients in probit, nonlinear regression models cannot be interpreted directly and we thus calculated marginal effects. These marginal effects for firm sales and firm (brand) awareness are $14 \%$ and $17 \%$, respectively. Further, the marginal effect of social performance accounts for a $5 \%$ increase in the probability of becoming a target. Companies incorporated in countries of high environmental attitude (consciousness) increase the targeting likelihood by $5 \%$. Companies incorporated in low-living quality countries increase their targeting likelihood by $2 \%$. The institutional parameters voice/accountability and political stability increase the targeting likelihood by $2 \%$ and $1 \%$, while with growing control of corruption the targeting likelihood increases by $3 \%$. The largest marginal effects were calculated for the service industries that range between $28 \%$ and $52 \%$.

\section{Model 2: Likelihood of Being Severely Criticized}

Regarding the likelihood of being severely targeted by Internet/media activism (Model 2 in Table 5), results regarding corporate factors are overall in line with what was observed for the General criticism sample, except that the coefficient regarding "Assets" is now significant, but only at the $10 \%$ level. 
Additionally, in contrast to what was observed for the General criticism model, industry effects appear more impactful as drivers of severe criticism. In line with H5, individual industry-fixed effects indicate that close-to-consumer operating industries attract unwanted Internet/media attention. Firms producing food/beverages, as well as Personal/household goods, which include the textile/fashion sector, or Automotive, are more likely to be targeted. Moreover, operating in controversially discussed industries such as mining and tobacco positively influences the likelihood of severe criticism, and therefore lends some support to $\mathrm{H} 4$.

On the country level, five variables seem to encourage criticism activity relative to firms: companies are especially targeted if they are incorporated in countries of high environmental attitudes, efficient corruption control, high educational levels and low unemployment rates. Again, these results seem very much in line with the idea that activists pick targets from countries that tend to be high in the Environmental Kuznets Curve, that is, countries in which citizens are likely to be sympathetic to the activists' cause.

With regard to the magnitude of the coefficients, the largest marginal effects were again estimated for the significant industry variables that range between $31 \%$ and $45 \%$. On the country level, low unemployment rates and high education levels increase the targeting likelihood by $10 \%$, supporting the idea that activists target firms to fit with a certain audience of educated and relatively wealthy readers. The remaining significant socioeconomic and institutional parameters show marginal effects between $2 \%$ and $6 \%$.

\section{Model 3: Determinants of Criticism Intensity}

Moving now to criticism as dependent variable, the results of the ordered probit specifications of Model 3 are presented in the third column of Table 5. The three cut-off levels are significant, suggesting that the proposed criticism thresholds constitute different severity levels of critical allegations. A positive sign of the coefficients implies a higher likelihood that the raised critique is harsh or very harsh. Regarding firm-specific factors, positive and significant coefficients can be observed for firm sales, and brand awareness, in line with H2. Results are also consistent with our previous estimates regarding industry effects: as for the likelihood of being severely targeted, criticism are more likely to be harsh for controversial sectors, like Mining or Tobacco, and for close-to-consumers sectors such as Food \& Beverage or Automotive. This is again consistent with H4. Together, these results support the idea of a relatively close connection between mundane and more severe criticism, and our concept of production chain for anticorporate campaigns. 
On the country level, factors such as companies being incorporated in countries with high environmental attitudes, education and anticorruption levels, and GDP growth rates raise the likelihood of more intense activism. At the same time, the negative signs of the two significant coefficients living quality and political stability indicate that inferior life quality also implies that Internet/media criticism will likely be severe. Again, our results regarding country-specific and international factors are thus not one-sided. Activists seem to engage both in strategic behaviors by making harsher criticism against firms from countries in which socioeconomic and institutional conditions will create a fertile ground for activists' claim, but activists also monitor and make harder criticism against companies from countries that are less stable institutionally and poorer. Both strategic and monitoring behaviors therefore seem to be at play.

\section{DISCUSSION - CONCLUSION}

This paper makes three contributions to the private politics literature. First, our results suggest that media/Internet criticism against firms seems to be driven by factors similar to what has been previously observed for full-fledged activist campaigns. As such, this study provides support to the idea that public criticism can be seen as the first step of a chain leading to the production of these campaigns. Depending on the model, firm sales, assets, and brand awareness positively influence the targeting likelihood. This is in line with studies showing that activists pick targets not only to highlight issues but also to attract attention and create legitimacy, which is more likely with large and visible firms (King \& Soule, 2007; Lenox \& Eesley, 2009). Internet/media criticism should therefore be seen as one of the first steps in private politics, potentially leading subsequently to larger campaigns, rather than standalone activities with their own logic.

Similarly, some of our results indicate that a firm's CSR orientation, as measured through its inclusion in DJSI, makes it more likely to be targeted. This is also in line with social movement/stakeholder theory in that transparently operating firms disclosing CSR-data offer more room for criticism (see, e.g., Luo et al., 2010). These findings also support the strategic accounting literature, which associates the provision of corporate information with a competitive disadvantage for the disclosing firm (see, e.g., Verrecchia, 2001). Alternatively, these firms might be particularly targeted by activists who suspect firms of "green-washing" Laufer (2003). 
Additionally, we also found that industry effects matter, especially in explaining more severe criticism. Companies operating in industries that are controversial (mining, tobacco) or close to final customers (e.g., food/ beverage, textile sector) seem to be preferred targets for activists when engaging in severe media criticism. These results indicate that, in these industries, activists might better emphasize the urgency and legitimacy of their claims and protests as suggested by stakeholder theory (Mitchell, Agle, \& Wood, 1997). Moreover, these findings endorse explanations stating that activists select these industries where they expect higher returns in terms of corporate compliance/responses to the activists' requests ex post (Baron \& Diermeier, 2007; King \& McDonnell, 2015). These results regarding industry effects are also in line with the boycott literature: consumers are willing to support a boycott as long as affordable substitute products are available (Diermeier \& van Mieghem, 2005). This is certainly the case in the food/beverage sector, and with personal/household goods and clothes.

One important implication of these results is that managers should not take criticism lightly. If criticism is already a strategic stage that might lead to the production of full campaign against their firm, managers need to anticipate and think about possible reactions even at this early criticism stage. This idea speaks to two streams of literature on private politics. First, it is in line with existing empirical results that show that negative public exposure, both in the media and in the Internet, has a significant and positive impact on the development of CSR activities among firms that are exposed (Zyglidopoulos, Carroll, Georgiadis, \& Siegel, 2012). Second, our analysis is also in line with the theoretical literature on private politics, which tend to suggest that full campaigns are often preempted and do not occur because both the activists and the firm have incentives to negotiate at early stages and avoid the costs for both of running the full campaign (Baron \& Diermeier, 2007). Criticism might thus be an important early point of contact between firms and activist, leading to the development of more sustainable practices even before any major conflict has emerged.

The second contribution of this paper to the literature has to do with how country-specific and institutional differences influence private politics, which have not been explored in previous literature. We find that both the occurrence and the intensity of criticism against firms are, at least partially, driven by these country-specific and institutional factors. Activists locate or mediatize their campaigns against firms in countries that are extreme in terms of institutional quality, as well as socioeconomic performance. Either 
they target firms incorporated in healthy and wealthy economies where an environmental consciousness is already highly advanced (DiMaggio \& Powell, 1983; Matten \& Moon, 2008), or they select companies that operate in unstable and poorer economies with less developed ecological sensitivity (Kaul, Conceicao, Le Goulven, \& Mendoza, 2003). In this latter case, NGOs/ media might specifically target firms operating in such countries to exert pressure on the firms taking on (more) social/environmental responsibility.

Overall, these results seem to suggest that activists pursue a twofold targeting strategy: selecting firms incorporated in high welfare-states where the audience is likely to be supportive, while at the same time also providing some monitoring of firms from countries with weaker economic contexts and less institutional stability. So, regarding their welfare impact, should we expect activists to provide the monitoring and whistle-blowing function that is necessary for private regulation to emerge? Overall, not entirely. Activists, even when they engage in criticism, are already working on the manufacturing of anticorporate campaigns and are therefore going to strategically select the countries, the industries and the firms they go after. So, should we be pessimistic about the role that activism can play in achieving sustainable development? Probably not either. Activists do play their role of agents of change in countries and industries for which, in line with the Environmental Kuznets Curve approach, there will be a favorable audience for their activities. As other countries continue to develop, the role that activists can play in sustainable development should expand as well.

\section{Limitations}

Despite the interesting and new findings presented and discussed above, this study is certainly subject to limitations. First, regarding the connection between our conceptual framework and our data, we did not test the sequential dimension of our campaign production chain. In particular, we did not study empirically the ordering going from the selection of countries, industries and firms to criticize and then ultimately leading to full-fledged campaigns. Even if it seems unlikely, it might be that campaigns come first and criticism heat up after that. Anecdotal evidence seems to speak against this (Wapner, 2009). However, this is something that should certainly be studied empirically as it would reinforce our understanding of the manufacturing of campaigns and its implication on firms. In the same way, it would be interesting to study why some criticism lead to full-fledged campaigns while others do not (Wright \& Boudet, 2012). 
Second, there are limitations to the data used here. By focusing on firms present in the Fortune survey, we chose to explore Internet/media criticism for very large companies that are likely to be primary targets for activists and providing country/institutional variations. It would be interesting to replicate the analysis for a broader sample of firms. That being said, it is unclear whether including smaller firms would dramatically change our results. Considering only large firms reduces the variation in the sample and should make it more difficult to obtain results regarding firm-specific dimensions.

Similarly, regarding institutional effects, we focused on institutional dimensions for firms' home countries. It would be, however, interesting to also explore what drives Internet/media criticism in host countries. If activists play a monitoring role and become substitutes for deficient governance in certain countries as well as counter-balance the influence of multinationals (Scherer \& Palazzo, 2011), then this role should be observed empirically in the foreign countries where these multinationals operate. This certainly should be explored in future research.

We also do not know if the higher scrutiny and severity of criticism in some countries is related to the fact that activists or NGOs "play tougher" or whether there are just more activists in these countries, and therefore more criticism. In that sense, future studies should explore how countryspecific factors and institutional conditions affect the supply of activism and how this supply of activism determine the number of criticism and of full campaigns that take place.

There are also potential endogeneity issues with some of our measures. For instance, our measure of environmental awareness might in fact be driven by previous activism. A larger dataset including many more years of observations should allow to address this type of concern in the future.

Fourth, one of the limitations of the data conducted here is that this data did not allow for a clear identification of who the criticizers were. Most of the criticism clearly comes from activists acting through the media and the Internet, but it is often very difficult to pinpoint where the criticism started and who started it. To better understand the drivers of private politics, this origin of criticism is something that needs to be studied in more details. It is also difficult to differentiate Internet versus media criticism. Publications such as The Economist, for instance, could be on paper or online. It would be interesting, however, to see whereas Internet criticism, as they can go viral, tend to become activists' preferred option and if they have a stronger impact on firms than traditional media.

Last, it would be interesting to study firm responses to the criticism they are confronted with (Lenox \& Eesley, 2009). As suggested earlier, one 
difference between criticism and full campaigns is that criticism does not necessarily call for a direct response. However, it does not mean that firms should not take actions. Should firms provide a public response, for instance through the media? In which circumstances would such a public response to criticism be the most appropriate? Conversely, should firms engage in self-regulation - for instance through CSR investment - once they have been criticized in order to prevent the occurrence of a full campaign? This is in fact what the theoretical literature would suggest. More theoretical and empirical work is warranted to provide answers to these questions.

To conclude, this study provides a first exploration of how activists select the firms they criticize and how this criticism potentially differs but also interacts with broader campaigns as studied in previous literature. Many questions, however, remain to be answered regarding the role that activists play in monitoring firms and the environmental or social issues these firms create, as well as, more generally, regarding the role that these activists can play in creating self-regulating and sustainable economic systems.

\section{NOTES}

1. Naturally, a private politics chain leading to a full campaign against one firm might also lead subsequently to another private politics chain targeting another firm, as suggested by the idea of sequential targeting (Baron \& Diermeier, 2007).

2. Criticism regarding companies comes from various sources (i.e., media, Internet postings, news agencies, NGO reports, etc.) reporting in English, Spanish, German, French, Italian, Portuguese, Mandarin, Korean, and Russian.

3. http://www.interbrand.com/en/best-global-brands/best-global-brands-2008/ best-global-brands-2010.aspx

4. http://www.sustainability-index.com/07_htmle/data/djsiworld.html

5. https://www.cdproject.net/en-US/Results/Pages/reports.aspx

6. http://hdr.undp.org/en/data/build/

7. http://epi.yale.edu/Countries

8. http://info.worldbank.org/governance/wgi/index.asp

\section{REFERENCES}

Argenti, P. A. (2004). Collaborating with activists: How Starbucks works with NGOs. California Management Review, 47, 91-114.

Barnett, M. L., \& Hoffmann, A. E. (2008). Beyond corporate reputation: Managing reputational interdependence. Corporate Reputation Review, 11(1), 1-9. 
Baron, D. P. (2003). Private politics. Journal of Economics and Management Strategy, 12, 31-66.

Baron, D. P., \& Diermeier, D. (2007). Strategic activism and nonmarket strategy. Journal of Economics and Management Strategv, 16, 599-634.

Bartley, T., \& Child, C. (2014). Shaming the corporation: The social production of targets and the anti-sweatshop movement. American Sociological Review, 79, 653-679.

Beck, T., \& Levine, R. (2005). Legal institutions and financial development. In C. Menard \& M. Shirley (Eds.), Handbook of new institutional economics (pp. 251-278). Dordrecht: Springer.

Beck, U. (2000). What is globalization? Cambridge: Polity Press.

Bonardi, J. P., \& Keim, G. (2005). Corporate political strategies for widely salient issues. Academv of Management Review, 30(3), 555-576.

Bunn, I. D. (2003-2004). Global advocacy for corporate accountability: Transatlantic perspectives from the NGO community. American University International Law Review, 19, 1265-1306.

Cole, M. A. (2000). Air pollution and 'dirty industries': How and why does the composition of manufacturing output change with economic development? Environmental and Resource Economics, 17(1), 109-123.

De Bakker, F. G. A., \& den Hond, F. (2008). Introducing the politics of stakeholder influence - A review essay. Business \& Societv, 47(1), 8-20.

Den Hond, F., \& de Bakker, F. (2007). Ideologically motivated activism: How activist groups influence corporate social change activities. Academv of Management Review, 32(3), 901-924.

Diermeier, D., \& van Mieghem, J. A. (2005, August). A stochastic model of consumer boycotts. Working Paper (COSM-05-001), Kellogg School of Management, Northwestern University.

DiMaggio, P. J., \& Powell, W. W. (1983). The iron cage revisited: Institutional isomorphism and collective rationality in organizational fields. American Sociological Review, 48, 147-160.

Doh, J. P., \& Guay, T. R. (2006). Corporate social responsibility, public policy, and NGO activism in Europe and the United States: An institutional-stakeholder perspective. Journal of Management Studies, 43(1), 47-73.

Dyck, A., \& Zingales, L. (2002). The corporate governance role of the media. In The right to tell. The role of mass media in economic development (pp. 107-137). Washington, DC: World Bank Institute.

Eesley, C., \& Lenox, M. J. (2006). Firm response to secondary stakeholder action. Strategic Management Journal, 27, 765-781.

Friedman, M. (1985). Consumer boycotts in the United States, 1970-1980: Contemporary events in historical perspective. Journal of Consumer Affairs, 19, 96-117.

Gallup, J. L., Sachs, J., \& Mellinger, A. D. (1999). Geography and economic development. International Regional Science Review, 22(2), 179-232.

Graves, S. B., Rehbein, K., \& Waddock, S. (2001). Fad and fashion in shareholder activism: The landscape of shareholder resolutions, 1988-1998. Business and Societv Review, 106(4), 293-314.

Halme, M., \& Huse, M. (1997). The influence of corporate governance, industry and country factors on environmental reporting. Scandinavian Journal of Management, 13(2), 137-157.

Hendry. (2006). Taking aim at business: What factors lead environmental non-governmental organizations to target particular firms? Business \& Society, 45, 47-86. 
John, A., \& Klein, J. G. (2003). The boycott puzzle: Consumer motivations for purchase sacrifice. Management Science, 49, 1196-1209.

Jones, M. T. (1999). The institutional determinants of social responsibility. Journal of Business Ethics, 20(2), 163-179.

Kaufmann, D., Kraay, A., \& Mastruzzi, M. (2009). Governance matters VIII: Aggregate and individual governance indicators, 1996-2008 (pp. 1-103). World Bank Policy Research Working Paper No. 4978.

Kaufmann, D., Kraay, A., \& Mastruzzi, M. (2011). The worldwide governance indicators: Methodology and analytical issues. Hague Journal on the Rule of Law, 3(02), 220-246.

Kaul, I., Conceicao, P., Le Goulven, K., \& Mendoza, R. U. (Eds.). (2003). Providing public goods. Managing globalization. New York, NY: Oxford University Press.

King, B., \& McDonnell, M. H. (2015). Good firms, good targets: The relationship between corporate social responsibility, reputation, and activist targeting. In $\underline{\mathrm{K}}$. Tsutsui \& A. Lim (Eds.), Corporate social responsibility in a globalizing world. Cambridge: Cambridge University Press.

King, B. G. (2008). A political mediation model of corporate response to social movement activism. Administrative Science Ouarterlv, 53, 395-421.

King, B. G., \& Pearce, N. A. (2010). The contentiousness of markets: Politics, social movements, and institutional change in markets. Annual Review of Sociology, 36, 249-267.

King, B. G., \& Soule, S. A. (2007). Social movements as extra-institutional entrepreneurs: The effect of protests on stock price returns. Administrative Science Quarterly, 52, 413-442.

Kingsley, A., Vanden Bergh, R., \& Bonardi, J. P. (2012). Political markets and uncertainty: Insights and implications for integrated strategy. Academv of Management Perspectives, 26, 52-67.

Koku, P. S., Akhigbe, A., \& Springer, T. M. (1997). The financial impact of boycotts and threats of boycotts. Journal of Business Research, 40, 15-20.

La Porta, R., Lopez-de-Silanes, F., Shleifer, A., \& Vishny, R. (1998). Law finance. Journal of Political Economy, 106, 1113-1155.

La Porta, R., Lopez-de-Silanes, F., Shleifer, A., \& Vishny, R. (2000). Investor protection and corporate governance. Journal of Financial Economic, 58, 3-27.

Lamin, A., \& Zaheer, S. (2012). Wall street vs. main street: Firm strategies for defending legitimacy and their impact on different stakeholders. Organization Science, 23(1), 47-66.

Laufer, W. S. (2003). Social accountability and corporate greenwashing. Journal of Business Ethics, 43, 253-261.

Lenox, M. J., \& Eesley, C. (2009). Private environmental activism and the selection and response of firm targets. Journal of Economics \& Management Strategy, 18(1), 45-73.

Luo, J., Meier, S., \& Oberholzer-Gee, F. (2010, May). What's news? CSR and corporate reputation management. Working Paper.

Matten, D., \& Moon, J. (2008). "Implicit" and "explicit" CSR: A conceptual framework for a comparative understanding of corporate social responsibility. Academv of Management Review, 33(2), 404-424.

Meznar, M. B., \& Nigh, D. (1995). Buffer or bridge? Environmental and organizational determinants of public affairs activities in American firms. Academv of Management Journal, 38(4), 975-996.

Mitchell, R. K., Agle, B. R., \& Wood, D. J. (1997). Toward a theory of stakeholder identification and salience: Defining the principle of who and what really counts. Academy of Management Review, 22(4), 853-886. 
Ocasio, W. (1997). Towards an attention-based view of the firm. Strategic Management Journal, 18, 187-206.

Pfeffer, J., \& Salancik, G. (1978). The external control of organizations: A resource dependence perspective. New York, NY: Harper \& Row.

Philippe, D., \& Durand, R. (2011). The impact of norm-conforming behaviors on firm reputation. Strategic Management Journal, 32, 969-993.

Rehbein, K., Waddock, S., \& Graves, S. B. (2004). Understanding shareholder activism: Which corporations are targeted. Business \& Society, 43(3), 239-267.

Sachs, J. (2003). Institutions don't rule: Direct effects of geographv on per capita income. NBER Working Paper Series No. 9490, Columbia University.

Sasser, E. N., Prakash, A., Cashore, B., \& Graeme, A. (2006). Direct targeting as an NGO political strategy: Examining private authority regimes in the forestry sector. Business and Politics, 8(3), Article 1.

Scherer, A., \& Palazzo, G. (2011). The new political role of business in a globalized world: A review of a new perspective on CSR and its implications for the firm, governance, and democracy. Journal of Management Studies, 48(4), 899-931.

Stern, D., Common, M., \& Barbier, E. (1996). Economic growth and environmental degradation: The environmental Kuznets curve and sustainable development. World Development, 24(7), 1151-1160.

Teegen, H., Doh, J. P., \& Vachani, S. (2004). The importance of Nongovernmental Organizations (NGO) in global governance and value creation: An international business research agenda. Journal of International Business Studies, 35, 463-483.

Verrecchia, R. E. (2001). Essays on disclosure. Journal of Accounting and Economics, $32,97-180$.

Wapner, P. (2009). Environmental activism and world civic politics. Albany, NY: State University of New York Press.

Weber, J., \& Marley, K. A. (2012). In search of stakeholder salience: Exploring corporate social and sustainability reports. Business \& Society, 51(4), 626-649.

Wright, R., \& Boudet, H. (2012). To act or not to act: Context, capability and community response to environmental risk. American Journal of Sociologv, 118(3), 728-777.

Yaziji, M. (2004). Turning gadflies into allies. Harvard Business Review, 82, 110-115.

Yaziji, M., \& Doh, J. (2009). NGOs and corporations: Conflict and collaboration. Cambridge: Cambridge University Press.

Yurday, E., \& Baron, D. P. (2004). Anatomy of a corporate campaign: Rainforest Action Network and Citigroup. Stanford Graduate School of Business, Case: P-42A.

Zyglidopoulos, S. C., Carroll, C. E., Georgiadis, A. P., \& Siegel, D. S. (2012). Does media attention drive corporate social responsibility? Journal of Business Research, 65, 1622-1627. 